\title{
Multi-Target Inhibitory Activity of Some Medicinal Plants on A-Amylase, Tyrosinase and Hyaluronidase: Potential Therapy for Treatment Diabetes and Diabetic Complications
}

\section{Rowida Omar' ${ }^{1}$ Amal Galala ${ }^{2}$ and Farid Badria ${ }^{2 *}$}

${ }^{1}$ Department of Pharmacognosy, Faculty of Pharmacy, Delta University for Science and Technology, International, Gamasa, Egypt ${ }^{2}$ Department of Pharmacognosy, Faculty of Pharmacy, Mansoura University, Mansoura, Egypt *Corresponding Author: Farid Badria, Department of Pharmacognosy, Faculty of Pharmacy, Mansoura University, Mansoura, Egypt.

Received: August 17, 2019; Published: September 13, 2019

\section{Abstract}

Multi - target enzyme inhibitors have gained a growing interest due to their fewer side effects compared to a single targeted or combination therapy. Medicinal plants can serve as a vast platform for bioactive molecules that could act as safe and effective multi - target enzyme inhibitors. Diabetes mellitus is a complicated metabolic disorder with several enzymes involved such as $\alpha$-amylase, tyrosinase and hyaluronidase. Out of 54 tested extracts, P. emblica and T. diffusa leaves extract exerted the highest inhibitory effect against $\alpha$ - amylase with 98.37 and 60.16\% inhibition, respectively. G. glabra stolon, propolis resin and C. splendens leaves extracts exhibited the highest tyrosinase inhibitory activity with $98.13 \pm 0.80,73.13 \pm 0.51$ and $65.52 \pm 0.68 \%$ inhibition, respectively. On the other hand, hyaluronidase enzyme, $P$. granatum, $P$. emblica, and $P$. guajava, showed the highest activity at $116.34 \pm 1.06 \% 115.77 \pm$ $0.45 \%$, and $103.44 \pm 0.78 \%$ respectively. Subsequently, this study revealed that only 6 extracts; Calligonum comosum, Camellia sinensis, Clerodendrum splendens, Phyllanthus emblica, Rumex acetosa, and Turnera diffusa, retained a multi - target inhibitory effect on the three tested enzymes. Interestingly, all 6 plants except Calligonum comosum are commonly used in folkloric medicine for diabetes modulation and our results rationalize their traditional use. Furthermore, the antioxidant capacity and the total phenolic content were determined for all extracts, where they showed potential anti - oxidant capacity related to their high total phenolic content. The obtained results prompted us to a preliminary conclusion towards the potential use of medicinal plants as multi - target enzyme inhibitors for the modulation of metabolic diseases such as Diabetes mellitus.

Keywords: Diabetes Mellitus; Enzyme Inhibitors; Medicinal Plants; Multi - Target

\section{Graphical Abstract:}

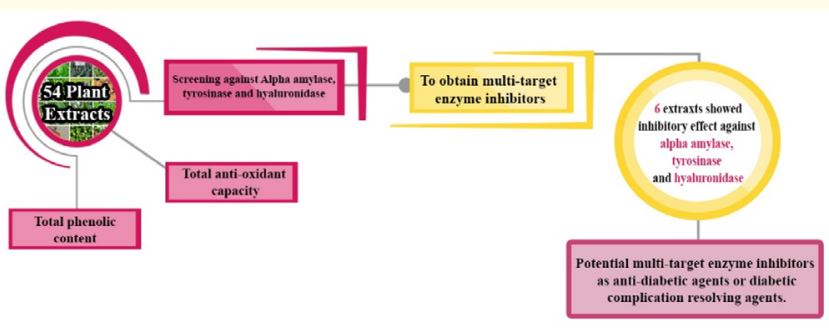

Figure A

\section{Introduction}

Natural products, their derivatives and traditional remedies have an uprising attention in drug discovery approaches. Natural products are characterized by their structural diversity so; they could be utilized as biological function modifiers. This open the door for the development of new technologies in discovering new drugs based on natural products' screening, because they are a rich wealth of bioactive compounds. These bioactive compounds have a disease inhibiting abilities with many advantages over the synthetic ones such as lower toxicity with more effectiveness. Natural products' ethnos pharmacological uses and pure compound isolation from their crude extracts are the basis of for developing a lead compound through natural products drug discovery [1].

Medicinal plants are a rich source of bioactive natural products which are used as active elements in modern medication. Currently, researchers in the study organizations through the world are seeking for inexpensive, effective, real and simple accessible natural compound enzyme inhibitor [2]. Enzyme inhibitors are mostly bioactive secondary metabolites binding with an enzyme to reduce its bioactivity. Subsequently, blocking enzyme activity can kill a pathogen or correct a metabolic imbalance. Many natural products are enzyme inhibitors characterized by their specificity, potency and effectiveness. great specificity and potency confirm that a medicinal drug will have few side effects and possess low toxicity [3]. 
There are number of examples which deal with enzymes as drug targets involved in the designing of new drugs, such as; olive and ginkgo extracts as potential cataract therapy with differential inhibitory activity on aldose reductase [4], botulinic acid analogues as potent topoisomerase inhibitors [5], and flavonoids containing an alpha-keto group as a new type of tyrosinase inhibitors from natural products as potential treatments for hyperpigmentation [6].

All of the previous examples are about using one compound that targets single enzyme (on - target approach), with high selectivity to avoid any unwanted effects arising from mis - targeting other biological targets (off - targets). On this basis, the concept of drugs inhibiting multiple targets has long been identified as undesirable, as it was associated with adverse effects. However, the complexity of the current incurable pathologies has clearly demonstrated that such single - target drugs are inadequate to achieve a therapeutic effect. In parallel, it was found that molecules hitting more than one target may have in principle a safer profile compared to singletargeted ones [7].

One of the common complex metabolic disorders is diabetes mellitus, which is characterized by very high plasma glucose levels (hyperglycemia), causing significant fluxes of glucose in tissues resulted in secondary complications such as peripheral neuropathy, skin disorders, and impaired wound healing ability [8]. Therefore, the control of postprandial hyperglycemia should be the first target to prevent and manage (DM) [9]. Upon inhibiting the $\alpha$ - amylase enzyme, the liberation of $\mathrm{D}$ - glucose from dietary complex carbohydrates can be retarded. Thus, $\alpha$ - amylase inhibitors play an important role in delaying the digestion and absorption of carbohydrates and hinder postprandial hyperglycemic deviation [10].

Skin hyperpigmentation disorders are one of the complications in diabetic patients as a result of oxidative stress due to hyperglycemia. For this reason, it could be useful to inhibit the tyrosinase enzyme, which regulates melanin synthesis $[11,12]$. These have motivated researchers to seek for novel dual - action compounds targeting the tyrosinase enzyme activity and possessing antioxidant properties. Moreover, impaired wound healing is a common problem in diabetic patients, which is mechanistically linked to hyperglycemia through the degradation of hyaluronan (HA) in the glycocalyx of endothelial cells (ECs) by the hyaluronidase enzyme. Such changes are likely to increase oxidative damage, impairing the process of wound healing [13].

Oxidative stress is one of the causative factors for DM complications [10], contributing to inflammation, carcinogenesis, cell proliferation, aging, and other complications [14]. Also, it could induce melanin biosynthesis, and may induce proliferation of melanocytes $[15,16]$. Therefore, adding the antioxidant/anti - stress activity to the multi - target effect of selected natural products on three enzymes; $\alpha$ - amylase, tyrosinase, and hyaluronidase will lead presumably to a potential therapeutic agent (s) for treatment of diabetes and diabetic complications.
This prompted us to search for bio - active natural products with inhibitory activities against enzymes involved in DM progression, such as $\alpha$ - amylase, tyrosinase and hyaluronidase. Fifty - four medicinal plants extracts were selected and tested for their in vitro $\alpha$ amylase, tyrosinase, and hyaluronidase inhibitory activity. The anti - oxidant potential and the total phenolic content of the samples were also measured.

\section{Materials and Methods}

Plant materials

Plants represented in Table 1 were collected from the farm of Faculty of Pharmacy and Faculty of agriculture, University of Mansoura, Egypt in November 2016. Unorganized drugs were purchased from Huaraz herbal store in Cairo. Samples were identified by Prof. Zain El - abdeen Abd El - Hameed Mohamed, Department of Agricultural Plants, Faculty of Agriculture, Mansoura University.

\begin{tabular}{|l|c|c|}
\hline \multicolumn{1}{|c|}{ Latin name } & Family & Part used \\
\hline Atropa belladonna & Solanaceae & Leaves \\
\hline Boswellia carterii & Burseraceae & Oleo-gum resin \\
\hline Camellia sinensis & Theaceae & Leaves \\
\hline Capsicum officinal & Solanaceae & Fruit \\
\hline Calligonum comosum & Polygonaceae & Leaves \\
\hline Catha edulis & Calastrales & Leaves \\
\hline Cinchona officinalis & Rubiaceae & Bark \\
\hline Cleome droserifolia & Cleomaceae & Leaves \\
\hline Clerodendrum splendens & Lamiaceae & Leaves \\
\hline $\begin{array}{l}\text { Coleuslumei(Plectranthus } \\
\text { scutellarioides) }\end{array}$ & Lamiaceae & Leaves \\
\hline Commiphora molmol & Burseraceae & Gum - Resin \\
\hline Coriandrum sativum & Apiaceae & Leaves \\
\hline $\begin{array}{l}\text { Cuphea } \text { hyssopifolia } \\
\text { Kunth }\end{array}$ & Lythraceae & Leaves \\
\hline Cymbopogon citratus & Poaceae & Leaves \\
\hline Cynanchum argel Delile & Apocynaceae & Leaves \\
\hline Cyperus routundus & Cyperaceae & Tubers \\
\hline Datura stramonium & Solanaceae & Leaves \\
\hline Echinops spinosissimus & Asteraceae & Seeds \\
\hline Gerbera jamesonii & Asteraceae & Leaves \\
\hline Glycyrrhiza glabra & Fabaceae & Stolon \\
\hline Hibiscus sabdariffa & Malvaceae & Leaves \\
\hline Hyoscyamus muticus & Solanaceae & Leaves \\
\hline Hyphaene thebaica & Arecaceae & Fruit \\
\hline Jasminum officinale & Oleaceae & Leaves \\
\hline Lantana camara & Verbnaceae & Leaves \\
\hline Lawsonia inermis & Lythraceae & Leaves \\
\hline Lepidium sativum & Brassicaceae & Seed \\
\hline Mangifera indica & Anacardiaceae & Leaves \\
\hline Mentha piperita & Lamiaceae & Leaves \\
\hline Moringa oleifera & Leaves \\
\hline
\end{tabular}


Multi-Target Inhibitory Activity of Some Medicinal Plants on A-Amylase, Tyrosinase and Hyaluronidase: Potential Therapy for Treatment Diabetes and Diabetic Complications

\begin{tabular}{|l|c|c|}
\hline Morus alba & Morceae & Leaves \\
\hline Nerium oleander & Apocynaceae & Leaves \\
\hline Ocimum sanctum & Lamiaceae & Leaves \\
\hline Olea europaea & Oleaceae & Leaves \\
\hline Phoenix dactylifera & Arecaceae & Seeds \\
\hline Phyllanthus emblica & Phyllanthaceae & Leaves \\
\hline Pinus palustris & Pinaceae & Resin \\
\hline Piper nigrum & Piperaceae & Fruit \\
\hline Pistacia lentiscus & Anacardiaceae & Leaves \\
\hline Pistacia vera & Anacardiaceae & Endocarp \\
\hline Propolis & - & Resin \\
\hline Psidium guajava & Myrtaceae & Leaves \\
\hline Punica granatum & Lythraceae & Leaves \\
\hline Quercus infectoria & Fagaceae & $\begin{array}{c}\text { Pathological } \\
\text { outgrowth }\end{array}$ \\
\hline Rosa damascena & Rosaceae & Leaves \\
\hline Rosmarinus officinalis & Lamiaceae & Leaves \\
\hline Rubia tinctorum & Rubiaceae & Roots \\
\hline Rumex acetosa & Polygonaceae & Leaves \\
\hline Saponaria officinalis & Caryophyllaceae & Roots \\
\hline Tamarix aphylla & Tamaricaceae & Leaves \\
\hline Thuja orientalis & Cupressaceae & Leaves \\
\hline Thymus vulgaris & Lamiaceae & Leaves \\
\hline Turnera diffusa & Passifloraceae & Leaves \\
\hline Withania somnifera & Solanaceae & Leaves \\
\hline
\end{tabular}

Table 1: List of medicinal plants investigated.

\section{Chemicals}

A - amylase from Aspergillus oryzae, Mushroom tyrosinase enzyme kojic acid, and L - tyrosine (Sigma Aldrich, St. Louis, USA), 3,5 - dinitrosalicylic acid (DNS, Euromedex, France), Hyaluronic acid (Hyalgan ${ }^{\circledR}$, Fidia Farmaceutici, Italy), tryptic soya broth (TSB, Neogen company, UK), tannic acid (Oxford, UK), human albumin (Diamond diagnostic, Egypt) and p - dimethyl amino benzaldehyde (PDMAB, Oxford, UK). All solvents and chemicals were of analytical grade. The bacterial strain S. aureus ATCC 6538 was used.

\section{Samples preparation}

About 200 grams from each medicinal plant and $100 \mathrm{~g}$ from each unorganized drug were extracted separately by methanol $(500 \mathrm{ml})$, the extraction was carried out at room temperature, repeated three times, the solvents from the combined extracts were evaporated by vacuum rotary evaporator, then dried in a desiccator till fixed weight.

\section{Total antioxidant capacity (TAC)}

Total antioxidant capacity (TAC) of extracts was measured spectrophotometrically using the phosphomolybdenum assay described by $[17,18]$. Briefly, $300 \mu \mathrm{l}$ of the extract solution $(1 \mathrm{mg} / \mathrm{ml}$

methanol) was added to $2700 \mu \mathrm{l}$ of phosphomolybdenum reagent in covered test tubes. Phosphomolybdenum reagent was prepared by adding $4 \mathrm{mM}$ ammonium molybdate and $28 \mathrm{mM}$ sodium phosphate to $0.6 \mathrm{M}$ sulfuric acid. The tubes were then incubated in $95^{\circ} \mathrm{C}$ water bath for $90 \mathrm{~m}$. The tubes were allowed to cool to room temperature before measuring the absorbance of the solutions spectrophotometrically at $695 \mathrm{~nm}$. $300 \mu \mathrm{l}$ of methanol was used in the blank instead of the extract. The antioxidant activity was expressed as micrograms per milliliter of ascorbic acid equivalents $(\mu \mathrm{g} / \mathrm{ml}$ of AAE).

\section{Total phenolic content (TPC)}

Total phenolics were determined using Folin - Ciocalteau reagents as described by [19]. Plant extract or gallic acid standard were mixed with $1.8 \mathrm{ml}$ of Folin - Ciocalteu reagent (prediluted 10 - fold with distilled water) and allowed to stand at room temperature for $5 \mathrm{~m}$, and then $1.2 \mathrm{ml}$ of sodium bicarbonate (7.5\%) was added to the mixture. After standing for $60 \mathrm{~m}$ at room temperature (in the dark), absorbance was measured at $650 \mathrm{~nm}$. Results were expressed as $\mu \mathrm{g}$ gallic acid equivalents (GAE).

\section{In vitro $\alpha$ - amylase inhibitory assay}

The $\alpha$ - amylase inhibitory assay was performed according to the assay described by [20] with minor modifications. To $250 \mu \mathrm{L}$ of $0.02 \mathrm{M}$ sodium phosphate buffer ( $\mathrm{pH} 6.9,0.006 \mathrm{M} \mathrm{NaCl})$ containing $\alpha$ - amylase enzyme ( $4 \mathrm{mg} / \mathrm{ml}), 250 \mu \mathrm{L}$ of each plant extract $(1 \mathrm{mg} /$ $\mathrm{ml}$ ) was added and incubated for $10 \mathrm{~m}$ at RT, then $250 \mu \mathrm{L}$ of $1 \%$ of soluble starch solution was added. The reaction mixtures were then kept for $3 \mathrm{~m}$ RT. A DNS color reagent $(250 \mu \mathrm{L})$ was added to stop the reaction and all mixtures were placed in a boiling water bath for $5 \mathrm{~m}$ and then cooled to RT Absorbance was measured at $540 \mathrm{~nm}$. Quercetin was used as positive control. The assay was conducted in triplicates, and $\alpha$-amylase inhibitory activity of the plant extracts was calculated using the formula:

$\%$ of inhibition $=([$ Abs control - Abs sample $] /$ Abs control $) \times 100$

\section{In vitro tyrosinase inhibitory assay}

Tyrosinase inhibitory assay was determined as described by [21]. Briefly, L - tyrosine was used as the substrate of the enzyme. Fifty $\mu \mathrm{L}$ plant extracts $(1 \mathrm{mg} / \mathrm{ml}), 50 \mu \mathrm{L}$ mushroom tyrosinase solution $(2 \mathrm{mg} / \mathrm{ml})$ and100 $\mu \mathrm{L}$ phosphate buffer $(50 \mathrm{mM}, \mathrm{pH} 6.8)$ were mixed and incubated for $10 \mathrm{~m}$ at $37{ }^{\circ} \mathrm{C}$. Afterward, $100 \mu \mathrm{L}$ of $\mathrm{L}$ - tyrosine ( $2 \mathrm{mM}$ ) was added. Then, the reaction mixture was incubated at $37^{\circ} \mathrm{C}$ for $20 \mathrm{~m}$. The amount of dopachrome formed is proportional to the color formation which was measured at 475 $\mathrm{nm}$. Kojic acid dissolved in DMSO was used as a positive control. The extract inhibitory potential towards tyrosinase enzyme was calculated as follows:

$\%$ of inhibition $=[($ Abs control - Abs sample $) /$ Abs control $] \times 100$

Phenotypic detection of hyaluronidase production in S. aureus Hyaluronidase production was evaluated as described by [22]. 


\section{In vitro hyaluronidase inhibitory assay}

The hyaluronidase inhibition assay was determined as described by [23] with minor modifications. S. aureus strains were grown at $37^{\circ} \mathrm{C}$ overnight in TSB with shaking, sub cultured 1:1000, and grown for $6 \mathrm{~h}$ at $37^{\circ} \mathrm{C}$. Spin - $\mathrm{X}$ filters was used to isolate spent culture medium with pore size $0.22 \mu \mathrm{m}$ and kept at $-20^{\circ} \mathrm{C}$ until used. A $50 \mu \mathrm{l}$ of spent culture medium was incubated at $37^{\circ} \mathrm{C}$ for $15 \mathrm{~m}$ with $50 \mu \mathrm{L}$ of $1 \mathrm{mg} / \mathrm{ml}$ plant extracts dissolved in DMSO. 100 $\mu \mathrm{L}$ hyaluronic acid with concentration $1 \mathrm{mg} / \mathrm{ml}$ was mixed. The reaction was allowed for $15 \mathrm{~m}$ at $37^{\circ} \mathrm{C}$ before it was stopped by adding $25 \mu \mathrm{l}$ of $0.8 \mathrm{M}$ sodium tetra borate solution. The reaction mixture was then boiled for $3 \mathrm{~m}$. $500 \mu \mathrm{L}$ freshly prepared PDMAB solution $(10 \%[\mathrm{wt} / \mathrm{v}], 12.5 \%[\mathrm{v} / \mathrm{v}] 10 \mathrm{M} \mathrm{HCl}$, and $87.5 \%$ [v/v] glacial acetic acid) was added. Tannic and ascorbic acid were used as standard inhibitors. The reaction mixtures were then placed in a 96 - well micro-plate. The plate was incubated for $20 \mathrm{~m}$ at $37^{\circ} \mathrm{C}$ to allow the color development. 100\% activity of the enzyme (control) was conducted with the same procedure but without the test or standard inhibitor which was replaced by $50 \mu \mathrm{L}$ of DMSO. While a blank for sample and control was used, this had all the components except the enzyme. Absorbance at $570 \mathrm{~nm}$ was measured using microplate reader and percentage of inhibition was calculated using the formula:

Percentage of inhibition $=[($ Abs control - Abs sample $) /$ Abs control] $\times 100$

Where Abs control is the absorbance of $100 \%$ activity of the enzyme and Abs sample is the absorbance of the test reaction mixture containing extract or the positive control.

\section{Results and Discussion}

Extracts of medicinal plants have an uprising interest as they could be used as multi - target enzyme inhibitors with anti - oxidant activity for treatment and management of various disorders with lower side effects. Based on the previous reports about using medicinal plants traditionally as anti-diabetic agents [24], $\alpha$ - amylase, tyrosinase, hyaluronidase and anti - oxidant activities of 54 medicinal plants were investigated in this study.

\section{Determination of anti - oxidant capacities [17]}

The extracts of all investigated plant materials showed anti oxidant activities, but with different degrees, extending from 12.72 \pm 0.85 to $379.25 \pm 5.61 \mu \mathrm{g} / \mathrm{ml} \mathrm{AAE}$. The resin of P. palustris showed the highest then $C$. sinensis (245.11 $\pm 3.95 \mu \mathrm{g} / \mathrm{ml} \mathrm{AAE}$ ) while Turnera diffusa leaves extract showed the lowest anti - oxidant potential. P. granatum, P. emblica, P. guajava, C. comosum, Propolis resin, $P$. lentiscus leaves, $R$. acetosa, $P$. dactylifera seeds, G. glabra stolon extracts and $C$. splendens, exhibited good anti - oxidant activities $(136.29,128.01,116.54,91.93,83.79,82.03,77.91,62.13,53.99$ and $52.91, \mu \mathrm{g} / \mathrm{ml} \mathrm{AAE}$, respectively). The anti - oxidant activities of these plant extracts are most likely due to their phenolic contents.

\section{Determination of total phenolic content}

Determination of total phenolic content for all investigated plant extracts was carried out by Folin - Ciocalteu colorimetric methods. The color produced is proportional to the amount of polyphenols present in plant extracts. The methanolic extract of $p$. emblica leaves showed the highest phenolic content followed by $C$. officinalis with 1064.30 and $880.06 \mu \mathrm{g} / \mathrm{ml} \mathrm{GAE}$, respectively. The lowest phenolic content was detected in P. nigrum with $15.21 \mu \mathrm{g} /$ ml GAE.

\section{A - amylase enzyme}

A - amylase inhibitors from medicinal plants give a new therapeutic method to the management of postprandial hyperglycemia by inhibiting glucose release from starch and the potential use in the management of obesity and diabetes mellitus. Artificial $\alpha$ - amylase inhibitors such as acarbose and voglibose cause various negative gastrointestinal symptoms and hepatic complications [10]. A - amylase inhibitors from phenolic herbal extracts are more benign, and consequently could be preferred as an alternative for inhibition of carbohydrate - digestion enzymes. Upcoming studies is pointed at studying the possible amylase inhibitory activity of additional phenolics present in plant extracts and at explaining phenolic interactions mechanisms that may improve inhibition of $\alpha$ - amylase enzyme activity [25].

In this study as presented in Table 2, P. emblica and T. diffusa leaves extract exerted the highest inhibitory effect against $\alpha$ - amylase with (98.37 and $60.16 \%$ inhibition, respectively) followed by $P$. palustris resin with (48.99\% inhibition) as represented in Figure 1 Vs. quercetin (76.09\%). P. emblica and T. diffusa were found among folk medicine for diabetes [26] and this study rationalize their traditional use. Among the other analyzed methanolic extracts $C$. droserifolia, C. Splendens, C. molmol resin, C. sinensis, B. carterii, C. comosum, and $R$. acetosa leaves extract exhibited moderate $\alpha$ - amylase inhibitory properties with 43.69, 39.86, 38.71, 37.46, 36.35, 36.14, and $35.41 \%$ inhibition, respectively.

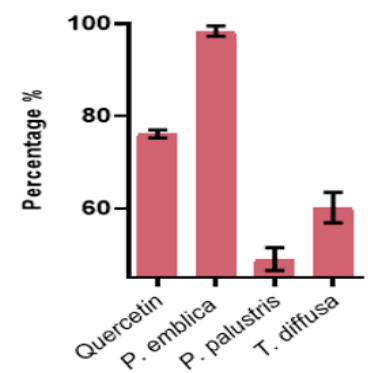

Figure 1: Percentage of inhibition for the methanolic Plant extracts after carrying out $\alpha$-amylase inhibitory assay using $\alpha$-amylase from Aspergillus oryzae and starch as the substrate, showing that p. emblica and T. diffusa leaves extract are the most active followed by P. palustris in comparison with Quercetin, the used positive control.

\section{Tyrosinase enzyme}

Table 2 showed G. glabra stolon, propolis resin and C. splendens leaves extracts exhibited the highest tyrosinase inhibitory activity $(98.13 \pm 0.80,73.13 \pm 0.51$ and $65.52 \pm 0.68 \%$ inhibition, 
Multi-Target Inhibitory Activity of Some Medicinal Plants on A-Amylase, Tyrosinase and Hyaluronidase: Potential Therapy for Treatment Diabetes and Diabetic Complications

\begin{tabular}{|c|c|c|c|c|c|}
\hline \multirow{2}{*}{ Latin name/ Family } & \multirow{2}{*}{$\begin{array}{c}\text { TAC } \\
(\mu \mathrm{g} / \mathrm{ml} \text { AAE })\end{array}$} & \multirow{2}{*}{$\begin{array}{c}\text { TPC } \\
(\mu \mathrm{g} / \mathrm{ml} \mathrm{GAE})\end{array}$} & \multicolumn{3}{|c|}{$\%$ Inhibition } \\
\hline & & & $\alpha$ - amylase & Tyrosinase & Hyaluronidase \\
\hline Camellia sinensis (leaves) Theaceae & $245.11 \pm 3.95$ & $195.36 \pm 3.21$ & $37.46 \pm 2.04$ & $41.00 \pm 1.83$ & $97.03 \pm 1.69$ \\
\hline Calligonum comosum (leaves) Polygonaceae & $91.93 \pm 2.82$ & $152.79 \pm 2.92$ & $36.14 \pm 1.46$ & $41.90 \pm 3.75$ & $93.36 \pm 3.18$ \\
\hline Clerodendrum splendens (leaves) Lamiaceae & $52.91 \pm 1.06$ & $139.45 \pm 1.82$ & $39.86 \pm 2.42$ & $65.52 \pm 0.68$ & $82.16 \pm 1.51$ \\
\hline Phyllanthus emblica (leaves) Phyllanthaceae & $128.01 \pm 2.54$ & $1064.30 \pm 4.10$ & $98.37 \pm 1.09$ & $52.84 \pm 1.39$ & $115.77 \pm 0.45$ \\
\hline Rumex acetosa (leaves) Polygonaceae & $77.91 \pm 3.61$ & $63.09 \pm 2.41$ & $35.41 \pm 1.82$ & $38.70 \pm 1.03$ & $70.43 \pm 0.45$ \\
\hline Turnera diffusa (leaves) Passifloraceae & $12.72 \pm 0.85$ & $-30.54 \pm 4.72$ & $60.16 \pm 3.30$ & $48.84 \pm 0.61$ & $37.43 \pm 1.29$ \\
\hline Quercetin & - & - & $76.09 \pm 0.87$ & - & - \\
\hline Kojic acid & - & - & - & $\begin{array}{c}108.78 \pm \\
0.82\end{array}$ & - \\
\hline Tannic acid & - & - & - & - & $91.24 \pm 0.49$ \\
\hline Ascorbic acid & - & - & - & - & $55.93 \pm 1.94$ \\
\hline
\end{tabular}

Table 2: List of the investigated medicinal plant extracts inhibitory activity against $\alpha$ amylase, tyrosinase and hyaluronidase, their total anti - oxidant capacity and total phenolic content as well as the positive controls.

The data is represented as mean \pm standard deviation (SD) for inhibition. The experiments were conducted in triplicates ( $\mathrm{n}=3)$.

respectively) in comparison with kojic acid which is the positive control with (108.78 $\pm 0.82 \%$ inhibition) as shown in Figure 2 . The other analyzed plants showed good tyrosinase inhibitory activity. Tyrosinase inhibitors are exploited for the prevention of skin diseases, and they are used in skin-whitening creams [27]. The previous studies have shown the presence of tyrosinase inhibitors in $G$. glabra stolon extract [6]. However, there were no previous reports about using C. Splendens and propolis as inhibitors of this enzyme. Therefore, they are considered to be new potential therapeutic agents for the treatment and management of hyperpigmentation.

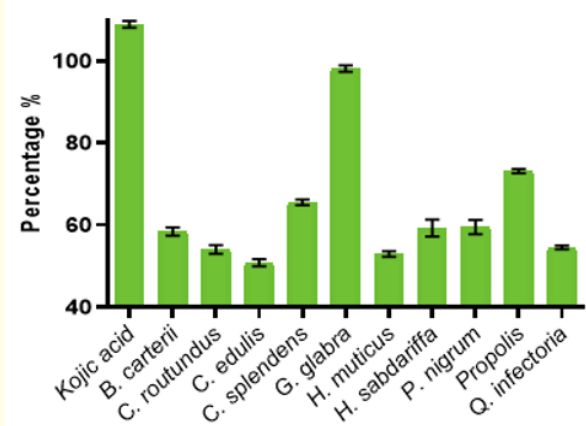

Figure 2: Percentage of inhibition for the methanolic plant extracts after carrying out tyrosinase inhibitory assay using mushroom tyrosinase and L-tyrosine as the substrate, showing that $G$. glabra stolon extract is the most active one followed by Propolis in comparison with kojic acid, the used positive control.

Phenotypic detection of hyaluronidase production in S. aureus

$S$. aureus bacterial growth was detected after $24 \mathrm{~h}$ of incubation. After washing the plates with $2 \mathrm{~N}$ glacial acetic acid, a clear zone around the bacteria was detected and the un - degraded hyaluronic acid formed a white precipitate in the rest of the plate. These observations indicated that $S$. aureus produced hyaluronidase enzyme which degrade the HA in the area around the bacterial growth.

\section{Hyaluronidase enzyme}

Table 2 shows the hyaluronidase inhibitory activity of the selected medicinal plant extracts using hyaluronic acid as substrate. The highest hyaluronidase inhibition was recorded in P. granatum leaves extract $116.34 \pm 1.06 \%$ followed by $P$. emblica $115.77 \pm$ $0.45 \%$, P. guajava $103.44 \pm 0.78 \%$, P. dactylifera $102.50 \pm 1.10 \%$, P. lentiscus $101.84 \pm 1.36 \%$, C. sinensis $97.03 \pm 1.69$ and C. comosum $93.36 \pm 3.18 \%$ inhibition. The previously mentioned plants exhibited stronger inhibitory activity than tannic acid and ascorbic acid (positive controls) with 91.24 and 55.93\% inhibition, respectively. L. sativum seeds and L. inermis leaves extracts are also good potential inhibitors for hyaluronidase with (84.51 and 83.15\% inhibition, respectively). The inhibition of hyaluronidase and the subsequent decrease in the breakdown of hyaluronic acid, result in a decrease in angiogenesis, inflammation solving the problem of impaired wound healing in diabetic patients [28]. They also could inhibit the hyaluronidase produced by the bacteria in the infected ulcers. Hyaluronic acid used in the synthesis of biological scaffolds for wound healing applications. These scaffolds typically have proteins such as fibronectin attached to the hyaluronan to facilitate cell migration into the wound. This is particularly important for individuals with diabetes suffering from chronic wounds [29]. The previous studies have revealed the existence of hyaluronidase inhibitors in P. granatum, C. sinensis [30]. However, hyaluronidase inhibitory activity was not reported in P. lentiscus leaves, P. dactylifera seeds and $C$. comosum leaves extract so, these plants considered as new potential sources for hyaluronidase inhibitors.

The previous findings revealed that six of the investigated plant extracts (C. comosum, C. sinensis, C. Splendens, p. emblica, R. acetosa and T. diffusa), could inhibit the three enzymes of interest as illustrated in Figure 4. P. palustris and T. diffusa extracts are active against only $\alpha$ - amylase and tyrosinase as shown in Figure 5, while nine plant extracts inhibited tyrosinase and hyaluronidase only as shown in Figure 6 


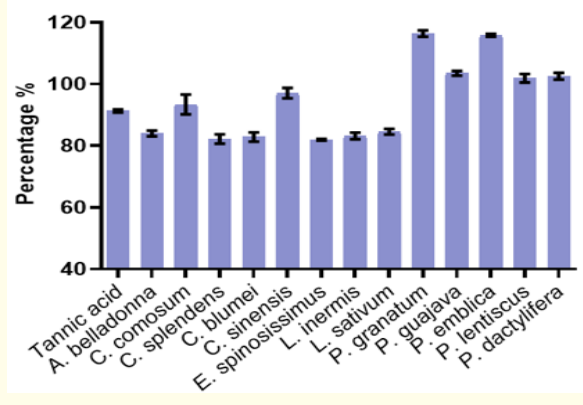

Figure 3: Percentage of inhibition for the methanolic plant extracts after carrying out the hyaluronidase inhibitory assay using bovine hyaluronidase and hyaluronic acid as the substrate, showing that $p$. granatum and p. emblica leaves extracts made a significant inhibition more than tannic acid, the used positive control.

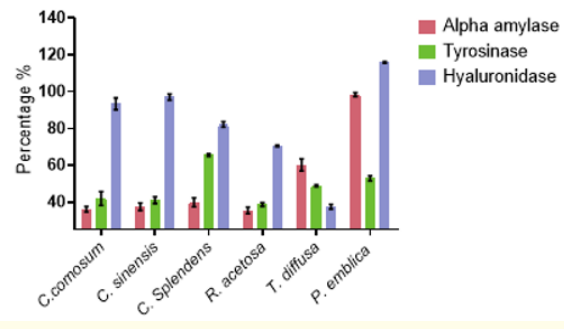

Figure 4: Methanolic plant extracts with multi-target inhibitory activity against alpha amylase, tyrosinase and hyaluronidase.

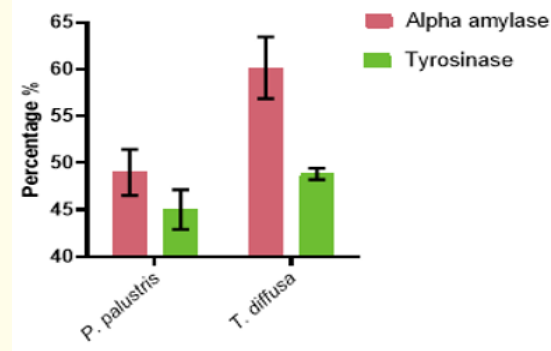

Figure 5: Methanolic plant extracts with both $\alpha$-amylase and tyrosinase inhibitory activity.

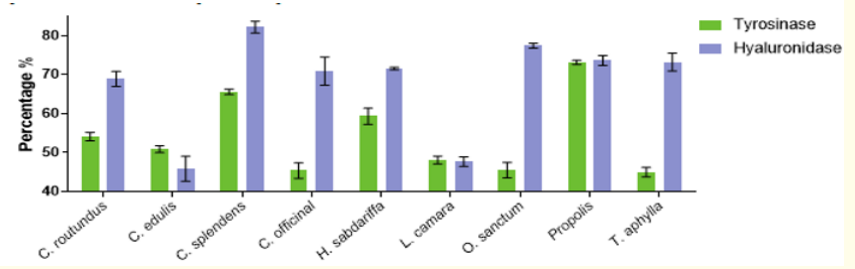

Figure 6: Methanolic plant extracts with both tyrosinase and hyaluronidase inhibitory activity.
The multi - target activity of those plant extracts supports the idea of management and treatment of DM as a complicated metabolic disorder. Hyperglycemia could be the cause of increasing the level of free radicals, leading to oxidative tissue damage and diabetic complications such as skin hyperpigmentation and impaired wound healing $[13,31]$. Therefore, the control of postprandial hyperglycemia is one of the main therapeutic approaches in the treatment of DM by $\alpha$ - amylase inhibitors and its complications by using tyrosinase and hyaluronidase inhibitors.

The previously mentioned multi - target plant extracts exhibited significant anti - oxidant potential with high polyphenolic content. Having dual hypoglycemic and antioxidant activities has considered to be the most effective and preferable anti - diabetic therapy because of its vital role in decreasing the hyperglycemia induced oxidative stress [32].

All of the multi - target plant extracts except $C$. comosum were previously reported in folkloric medicine as anti - diabetic agents. This study confirms the presence of bio - active secondary metabolites acting as enzyme inhibitors, validating their traditional use in the treatment of DM.

\section{Conclusion}

Based upon the inhibitory activity to three enzymes related to metabolism, good antioxidant activity, and high phenolic contents, Calligonum comosum, Camellia sinensis, Clerodendrum Splendens, phyllanthus emblica, Rumex acetosa and Turnera diffusa leaves extracts we may propose the possible promising multi - target enzyme inhibitors, as anti - diabetic agents and/or in the modulation of diabetic complications. The multi - target enzyme inhibition of these extracts could be correlated to their high anti - oxidant polyphenols content. Further phytochemical, computer - aided designed (CAD), molecular biology, and in vivo toxicity studies are currently under investigation for these active crude extracts to determine the major bio - active compounds which is/are responsible for their multiple inhibitory activity against $\alpha$ - amylase, tyrosinase and hyaluronidase as well as the mechanism of action.

\section{Bibliography}

1. Koparde AA., et al. "Natural Products in Drug Discovery, in Pharmacognosy-Medicinal". Natural Products in Drug Discovery (2019).

2. Uddin G., et al. "Preliminary comparative phytochemical screening of Diospyros lotus Stewart". Middle East Journal of Scientific Research 10.1 (2011): 78-81.

3. Rauf A and Jehan N. Natural products as a potential enzyme inhibitors from medicinal plants, in Enzyme Inhibitors and Activators (2017): 165-177.

4. Elimam DMA., et al. "Olive and ginkgo extracts as potential cataract therapy with differential inhibitory activity on aldose reductase". Drug Discoveries and Therapeutics 11.1 (2017): 41-46. 
5. Bar FMA., et al. "Rational design and semisynthesis of betulinic acid analogues as potent topoisomerase inhibitors". Journal of Natural Products 72.9 (2009): 1643-1650.

6. Badria F. "A new type of tyrosinase inhibitors from natural products as potential treatments for hyperpigmentation". Bollettino Chimico Farmaceutico 140.4 (2001): 267-271.

7. Ramsay RR., et al. "A perspective on multi-target drug discovery and design for complex diseases". Clinical and Translational Medicine 7.1 (2018): 3.

8. Ahmed N. "Advanced glycation endproducts-role in pathology of diabetic complications". Diabetes Research and Clinical Practice 67.1 (2005): 3-21.

9. Mitra A., et al. "Dietary influence on TYPE 2 Diabetes (NIDDM)”. Journal of Human Ecology 21.2 (2007): 139-147.

10. Keerthana G., et al. "In Vitro $\alpha$-amylase inhibitory and anti-oxidant activities of ethanolic leaf extract of Croton bonplandianum". Asian Journal of Pharmaceutical and Clinical Research 6.4 (2013): 32-36.

11. Mastore M., et al. "Production and utilization of hydrogen peroxide associated with melanogenesis and tyrosinase-mediated oxidations of DOPA and dopamine". The FEBS Journal 272.10 (2005): 2407-2415.

12. Schulze PC., et al. "Hyperglycemia promotes oxidative stress through inhibition of thioredoxin function by thioredoxininteracting protein". Journal of Biological Chemistry 279.29 (2004): 30369-30374.

13. Shakya S., et al. "Hyperglycemia-induced changes in hyaluronan contribute to impaired skin wound healing in diabetes: review and perspective". International Journal of Cell Biology (2015).

14. Liyanaarachchi GD., et al. "Tyrosinase, elastase, hyaluronidase, inhibitory and antioxidant activity of Sri Lankan medicinal plants for novel cosmeceuticals". Industrial Crops and Products 111 (2018): 597-605.

15. Fisher GJ., et al. "Mechanisms of photoaging and chronological skin aging". Archives of Dermatology 138.11 (2002): 14621470 .

16. Inomata S., et al. "Possible involvement of gelatinases in basement membrane damage and wrinkle formation in chronically ultraviolet B-exposed hairless mouse". Journal of Investigative Dermatology 120.1 (2003): 128-134.

17. Baig H., et al. "In vitro evaluation of antioxidant properties of different solvent extracts of Rumex acetosella leaves". Oriental Journal of Chemistry 27.4 (2011): 1509.
18. Kasangana P., et al. "Study of polyphenol content and antioxidant capacity of Myrianthus arboreus (Cecropiaceae) root bark extracts". Antioxidants 4.2 (2015): 410-426.

19. Biglari F., et al. "Antioxidant activity and phenolic content of various date palm (Phoenix dactylifera) fruits from Iran". Food chemistry 107.4 (2008): 1636-1641.

20. Jayasri M., et al. " $\alpha$-amylase and $\alpha$-glucosidase inhibitory activity of Costus pictus D. Don in the management of diabetes". Journal of Herbal Medicine and Toxicology 3.1 (2009): 91-94.

21. Chiari M., et al. "Tyrosinase inhibitory activity of native plants from central Argentina: Isolation of an active principle from Lithrea molleoides". Food Chemistry 120.1 (2010): 10-14.

22. Tyner H and Patel R. "Hyaluronidase in clinical isolates of Propionibacterium acnes". International Journal of Bacteriology (2015).

23. Ibberson CB., et al. "Staphylococcus aureus hyaluronidase is a CodY-regulated virulence factor". Infection and Immunity 82.10 (2014): 4253-4264.

24. Sharafetdinov KK., et al. "Promising Plant Sources of AntiDiabetic Micronutrients". Journal of Diabetes and Metabolism 8.12 (2017)

25. Rasouli H., et al. "Differential $\alpha$-amylase/ $\alpha$-glucosidase inhibitory activities of plant-derived phenolic compounds: a virtual screening perspective for the treatment of obesity and diabetes". Food and Function 8.5 (2017): 1942-1954.

26. Szewczyk K and Zidorn C. "Ethnobotany, phytochemistry, and bioactivity of the genus Turnera (Passifloraceae) with a focus on damiana-Turnera diffusa". Journal of Ethnopharmacology 152.3 (2014): 424-443.

27. Deri B., et al. "The unravelling of the complex pattern of tyrosinase inhibition". Scientific Reports 6 (2016): 34993.

28. Aya KL and Stern R. "Hyaluronan in wound healing: rediscovering a major player". Wound Repair and Regeneration 22.5 (2014): 579-593.

29. Kumbar S., et al. "Natural and synthetic biomedical polymers". (2014).

30. Félix-Silva J., et al. "Inhibition of local effects induced by Bothrops erythromelas snake venom: assessment of the effectiveness of Brazilian polyvalent bothropic antivenom and aqueous leaf extract of Jatropha gossypiifolia”. Toxicon 125 (2017): 74-83. 
31. Salah NM., et al. "Acetylcholinesterase, alpha-glucosidase and tyrosinase inhibitors from Egyptian propolis". International Journal of Pharmacognosy Phytochemistry Research 9 (2017): 528-536.

32. Hsieh P-C., et al. "Activities of antioxidants, $\alpha$-Glucosidase inhibitors and aldose reductase inhibitors of the aqueous extracts of four Flemingia species in Taiwan". Botanical Studies 51.293 (2010): 302.

Volume 3 Issue 10 October 2019

(C) All rights are reserved by Farid Badria., et al. 